\title{
First characterization of endophytic Corynespora cassiicola isolates with variant cassiicolin genes recovered from rubber trees in Brazil
}

\author{
Marine Déon - Ana Scomparin - Aude Tixier • \\ Carlos R. R. Mattos • Thierry Leroy • Marc Seguin • \\ Patricia Roeckel-Drevet • Valérie Pujade-Renaud
}

Received: 28 December 2011 / Accepted: 30 March 2012 / Published online: 27 April 2012

(C) The Author(s) 2012. This article is published with open access at Springerlink.com

\begin{abstract}
Corynespora cassiicola is the causal agent of Corynespora Leaf Fall (CLF) disease. CLF is one of the most important fungal diseases of rubber trees in Asia and Africa but disease outbreaks have not been reported in South America. Cassiicolin, a small cysteine-rich glycoprotein secreted by the pathogenic $C$. cassiicola isolate CCP, was previously identified as a potential disease effector in rubber tree. Recently, the cassiicolin-encoding gene (Cas 1) was characterized and shown to be expressed in the early phase of infection. In this study, we investigated whether previously undetected strains of $C$. cassiicola are present in South American rubber plantations by examining the fungal endophyte population found in asymptomatic rubber tree leaves. Four isolates were identified as C. cassiicola. Genes encoding new forms of the cassiicolin precursor protein (Cas3 and Cas4) were identified from these isolates.
\end{abstract}

Electronic supplementary material The online version of this article (doi:10.1007/s13225-012-0169-6) contains supplementary material, which is available to authorized users.

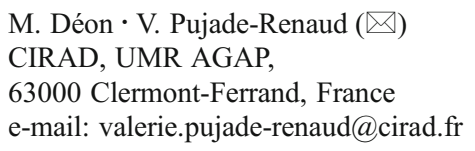

M. Déon · A. Scomparin · A. Tixier · P. Roeckel-Drevet Clermont Université, Université Blaise Pascal, UMR 547 PIAF, 63000 Clermont-Ferrand, France

C. R. R. Mattos

Plantações Michelin de Bahia,

Box 02, 45435-000 Ituberá, Bahia, Brazil

T. Leroy $\cdot$ M. Seguin

CIRAD, UMR AGAP,

34398 Montpellier, France
Three of four isolates were able to induce symptoms on the cultivar they were isolated from in a detached leaf assay, with different kinetics and intensities. One isolate had the same pathogenicity profile as the pathogenic isolate CCP; the other two isolates developed symptoms late during the course of infection, suggesting saprotrophic capabilities. However, no Cas3 or Cas 4 transcripts could be detected upon inoculation with the endophytic isolates, whereas the reference gene Cas 1 was expressed upon inoculation with the CCP isolate. This work demonstrated that C. cassiicola is present in South America in an endophytic form and that it may evolve from an endophytic to a saprophytic or even potentially pathogenic life style.

Keywords Corynespora cassiicola $\cdot$ Rubber tree · Endophyte $\cdot$ Brazil $\cdot$ Cassiicolin

\section{Introduction}

Corynespora cassiicola (Berk \& M. A. Curtis) C.T. Wei is an anamorphic Ascomycota fungus belonging to the Dothideomycetes and forming a separate phylogenetic clade among the Pleosporaceae with Corynespora smithii (Schoch et al. 2009). It has been found on leaves, stems, fruits and roots of more than 300 plant species primarily in tropical and subtropical areas (http://nt.ars-grin.gov/ fungaldatabases/; Farr and Rossman 2011). Principally described as a pathogen, it causes severe damage to economically important plants, including rubber tree, tomato, cucumber, cotton and soybean (Chee 1990; Koenning et al. 2006; Oliveira et al. 2006, 2007; Schlub et al. 2009). However, $C$. cassiicola isolates were also obtained from dead organic material (Kingsland 1985; Lee et al. 2004; Cai et al. 2006) and 
asymptomatic tissues (Collado et al. 1999; Suryanarayanan et al. 2002; Gond et al. 2007; Promputtha et al. 2007), and were therefore designated as saprophytes and endophytes, respectively.

In the rubber tree, C. cassiicola has thus far been exclusively known as a necrotrophic pathogen that causes the Corynespora Leaf Fall (CLF) disease, which ranks among the most important fungal diseases in Asian and African rubber plantations. Initially, C. cassiicola was described as a minor pathogen capable of attacking only budwood or seedling nursery plants (Newsam 1960; Chee 1988), but in 1975, the first epidemic outbreak on a plantation scale occurred in Indonesia. In the 1980s, several other countries in Southeast Asia were severely affected by disease outbreaks and thousands of hectares of rubber trees were uprooted in Malaysia, Indonesia, Thailand and Sri Lanka (Liyanage et al. 1986; Pongthep 1987; Chee 1988). By the end of the 1980s, African countries were also affected by CLF. The disease severity further increased until several important rubber tree cultivars considered to be tolerant or resistant to CLF during the first epidemic in the mid 1980s succumbed to the disease (Jayasinghe and Silva 1996; Shamsul and Shamsuri 1996; Sinulingga et al. 1996; Wahounou et al. 1996). Currently, all Asian and African rubber-producing countries, which account for $98 \%$ of the natural rubber production in the world (94 and $4 \%$ for each continent, respectively), are affected by the disease resulting in considerable economic losses.

CLF is characterized by necrotic lesions that develop on both young and mature leaves and lead to extensive defoliation. The fungus typically causes areas of necrosis with a fish bone appearance due to the darkening of the veins adjacent to the lesions (Chee 1988; Liyanage and Liyanage 1986; Pongthep 1987). However, the symptoms vary depending on the age, type and location of the rubber tree (Jayasinghe et al. 1998). This symptom variability impedes diagnosis of the disease in a plantation. Additionally, C. cassiicola isolates within the same agroclimatic zone vary widely in morphology, colony color, growth, spore production, pathogenicity and genetic diversity (Darmono et al. 1996; Jayasinghe and Silva 1996; Breton et al. 2000; Atan and Hamid 2003; Romruensukharom et al. 2005; Dixon et al. 2009; Qi et al. 2009).

Colonization of the rubber tree tissues by $C$. cassiicola involves the secretion of phytotoxic molecules (Onesirosan et al. 1975; Liyanage and Liyanage 1986; Purwantara 1987; Nugawela et al. 1989; Breton et al. 2000). A toxin called cassiicolin was purified and characterized from the culture filtrate of a rubber tree isolate (CCP) from the Philippines (Breton et al. 2000; Barthe et al. 2007; de Lamotte et al. 2007). The toxin is a small, secreted glycosylated protein that plays an important role in C. cassiicola pathogenicity. The cassiicolin-encoding gene encodes a precursor protein containing a signal peptide at the amino terminus that is predicted to target the protein for secretion (Déon et al. 2012). This gene is expressed one or two days postinoculation, suggesting a role in the early phase of infection.

Only a single report mentions CLF symptoms on Hevea brasiliensis growing in the American continent (Junqueira et al. 1985). In this area, C. cassiicola remains benign on rubber trees but causes significant damage to many other plant species. Could outbreaks of CLF disease occur in South American rubber plantations? To answer this question, we investigated whether previously undetected strains of the pathogen were present in rubber plantations in this area. The purpose of our study was to test for the presence of C. cassiicola among fungal rubber tree endophytes from a plantation in Brazil that had no history of the disease and to characterize these isolates.

\section{Material and methods}

\section{Plant material}

Fungal endophytes were recovered from young Hevea brasiliensis trees in nurseries consisting of 10 different cultivars (CDC 312, CDC 1174, FDR 5240, FDR 5665, FDR 5788, GT 1, MDF 180, PB 260, PMB 1 and RRIM 600) from a rubber tree plantation in Bahia, Brazil. The plants used for the inoculation and gene expression experiments (cultivars RRIM 600 and FDR 5788) were cultivated in a greenhouse in Clermont-Ferrand (France) at $28{ }^{\circ} \mathrm{C} \pm 2{ }^{\circ} \mathrm{C}$ with $80 \%$ relative humidity. All of the cultivars were grafted clones.

Isolation of endophytic fungi from asymptomatic Brazilian rubber tree leaves

Fungal endophytes were isolated from asymptomatic mature leaves that were collected in the nurseries and kept at room temperature for 8 days. Leaf segments were surfacesterilized through sequential immersion in $70 \%$ ethanol (1 $\mathrm{min}), 2 \%$ sodium hypochlorite solution ( $2 \mathrm{~min}$ ), $70 \%$ $(\mathrm{v} / \mathrm{v})$ ethanol $(30 \mathrm{~s})$ and sterile water. Leaf pieces with freshly cut edges were plated on Malt Extract Agar (MEA) supplemented with $0.02 \%$ chloramphenicol and placed at $25{ }^{\circ} \mathrm{C}$ in the dark. The emergent fungi were isolated by successive subcultures.

Molecular identification of endophytic fungi

All fungal isolates were grown from single conidia and verified by sequencing the internal transcribed spacer (ITS) region of the ribosomal DNA. For DNA extraction the isolates were grown on Potato Dextrose Agar (PDA) for 13 days in the dark. The mycelia was collected, frozen in 
liquid nitrogen and lyophilised. The genomic DNA was extracted as described previously (Risterucci et al. 2000). The ITS1, 5.8S, and ITS2 regions of the ribosomal DNA were amplified by PCR from $100 \mathrm{ng}$ of genomic DNA in a $50 \mu \mathrm{l}$ reaction mix containing $0.2 \mu \mathrm{M}$ of the ITS1 and ITS4 primers (White et al. 1990), $200 \mu \mathrm{M}$ of the dNTP mix, $2 \mathrm{mM}$ of $\mathrm{MgCl}_{2}, 1 \times$ buffer and $1 \mathrm{U}$ of Taq DNA polymerase (Qbiogen, Illkirch, France). The PCR was conducted for 30 cycles under the following conditions: $45 \mathrm{~s}$ at $94{ }^{\circ} \mathrm{C}, 45 \mathrm{~s}$ at $55^{\circ} \mathrm{C}$ and $45 \mathrm{~s}$ at $72{ }^{\circ} \mathrm{C}$. The PCR products were sequenced by GATC Biotech (Konstanz, Germany). Percentages of sequence similarity and coverage were determined by comparative similarity analyses with available sequences in the NCBI database using the Blastn program. Detailed results are given as Electronic Supplementary Material (ESM 1).

\section{Detached-leaf assay}

The $C$. cassiicola isolates were cultivated on PDA at $25^{\circ} \mathrm{C}$ with a $12 \mathrm{~h}$ photoperiod. The conidia were collected and resuspended in sterile water supplemented with $0.02 \%$ Tween 20 at a concentration of 5000 conidia/ml. For each isolate, six leaves were inoculated, each with ten drops of $20 \mu \mathrm{l}$ conidia suspension applied to the abaxial surface of detached rubber tree leaflets in developmental stage $\mathrm{C}$ (brownish to limp green) (Hallé and Martin 1968). One additional drop of $20 \mu \mathrm{l}$ of sterile water supplemented with $0.02 \%$ Tween 20 was added to each leaflet as negative control. The leaflets were maintained in a moist environment at $25{ }^{\circ} \mathrm{C}$ for $24 \mathrm{~h}$ in the dark and then under alternate light with a $12 \mathrm{~h}$ photoperiod. The conidial suspension was evaporated four days after the inoculation. The lesion area per leaflet was measured manually, at 5 and 9 dpi. The entire experiment was conducted three times. The symptoms intensity (SI) was expressed as the mean lesion area \pm the standard error from the 18 inoculated leaves (six leaflets per inoculation and three biological replicates).

Detection of cassiicolin gene homologues

Detection of cassiicolin gene homologues by PCR was conducted on the four C. cassiicola isolates (E70, E78, E79 and E139) from asymptomatic mature rubber tree leaves. The first set of primers was designed from the Cas sequence from isolate CCP (EF667973) and included CasF9, CasF11, CasF12, CasR16, CasR20 and CasR19. The second set of primers, CT1F9, CasF14, CT1R16 and CasR22, was designed from the CT1 sequence from the isolate CC004 (GU373809). Primer sequences are listed in the Electronic Supplementray Material ESM 2. PCR was performed on $100 \mathrm{ng}$ of C. cassiicola genomic DNA for 30 cycles $\left(45 \mathrm{~s}\right.$ at $94{ }^{\circ} \mathrm{C}, 45 \mathrm{~s}$ at $50{ }^{\circ} \mathrm{C}, 45 \mathrm{~s}$ at $\left.72{ }^{\circ} \mathrm{C}\right)$ using the same PCR components described above.
Cloning of full-length Cassiicolin gene homologues

The full-length sequence of the cassiicolin gene homologue Cas 3 was obtained by genome walking (Sallaud et al. 2003). This method allows for amplification of the $5^{\prime}$ and $3^{\prime}$ flanking regions of a target gene. Genomic DNA from isolate E70 was digested with 30 units of a restriction enzyme generating $3^{\prime}$ blunt overhangs. Four restriction enzymes were tested independently: EcoRV, DraI, PvuII and StuI (New England Biolabs). The digested products were purified using the QIAquick PCR Purification Kit (Qiagen, Courtaboeuf, France) and ligated to the ADPR1/ ADPR2 adaptor by $\mathrm{T} 4 \mathrm{DNA}$ ligase at $16{ }^{\circ} \mathrm{C}$ overnight in a final volume of $20 \mu \mathrm{l}$. The first PCR was performed with $1 \mu \mathrm{l}$ of the ligation/digestion using the primer AP1, which is specific to the ADPR1 adaptor, and a primer specific to the Cas 3 partial sequence obtained previously from isolate E70 using the CasF9/CasR20 primer pair. The second PCR was performed with $2 \mu \mathrm{l}$ of a 1/50 dilution of the PCR1 product using the nested primer AP2 (specific to the ADPR2 adapter) and a Cas3-specific nested primer. To obtain the 5' flanking region, the primers AP1/CasR20 and AP2/CasWE70-R04 were used for PCR1 and PCR2, respectively. To obtain the $3^{\prime}$ flanking region, the primers AP1/CasF9 and AP2/CasW-E70-F04 were used for PCR1 and PCR2, respectively. PCR reactions were performed in $1 \times$ buffer containing $1.5 \mathrm{mM}$ of $\mathrm{MgCl}_{2}, 200 \mu \mathrm{M}$ of dNTPs, $200 \mathrm{nM}$ of the adaptor, $0.2 \mu \mathrm{M}$ of the Cas-specific primer and $0.5 \mathrm{U}$ of Taq DNA polymerase (Eurobio, Courtaboeuf, France). All PCRs were conducted under the following conditions: an initial denaturation step $\left(4 \mathrm{~min}\right.$ at $\left.95{ }^{\circ} \mathrm{C}\right)$, then 40 cycles $\left(30 \mathrm{~s}\right.$ at $95{ }^{\circ} \mathrm{C}, 30 \mathrm{~s}$ at $58{ }^{\circ} \mathrm{C}, 2$ min at $\left.72{ }^{\circ} \mathrm{C}\right)$ and a final extension step $\left(72{ }^{\circ} \mathrm{C}\right.$ for $5 \mathrm{~min})$. PCR products migrating as a single unique band after electrophoresis on an agarose gel were directly sequenced using nested Cas3-specific primers: CasW-E70R01 for the $5^{\prime}$ flanking region and CasW-E70-F05 for the $3^{\prime}$ flanking region. A new set of primers (CasF20 and CasR28) was designed from both ends of the $5^{\prime}$ and $3^{\prime}$ flanking sequences and used to amplify the complete Cas 3 or Cas 4 sequence from isolates E70, E78, E79 and E139 using the AccuPrime ${ }^{\mathrm{TM}}$ Pfx proofreading DNA polymerase (Invitrogen, Paisley, UK) according to the manufacturer's recommendations. All of the primers used in this study are listed in the Electronic Supplementary Material ESM 2.

Bioinformatics

All nucleotide and amino acid sequence analyses, alignments and annotations were conducted using the Geneious Pro program (Drummond et al. 2011). Homology searches were performed using the Blast program in the NCBI 
database. A phylogenetic tree of the cassiicolin gene diversity was constructed using MEGA5 software (Tamura et al. 2007 ) by the Neighbor-Joining method (Saitou and Nei 1987). The analysis involved six nucleotide sequences: JF915169, JF915170, JF915171, JF915172, GU373809 and EF667973, for isolates E70, E78, E79, E139, CC004 and CCP respectively. The codon positions included in the analysis were $1 \mathrm{st}+2 \mathrm{nd}+3 \mathrm{rd}+$ Noncoding. All positions containing gaps and missing data were eliminated. There was a total of 574 positions in the final dataset. A bootstrap test of 1000 replicates was performed to obtain the percentage in which the associated taxa clustered together (Felsenstein 1985). The evolutionary distances were computed using the p-distance method (Nei and Kumar 2000), and the results were expressed as the number of base differences per site.

The synonymous $\left(d_{S}\right)$ and non-synonymous $\left(d_{N}\right)$ substitution rates were calculated by codeml in the PAML package (Goldman and Yang 1994).

The prediction of the signal peptide in the protein was performed using SignalP software, version 3.0 (Bendtsen et al. 2004), and the program TMHMM, version 2.0, was used to check for the presence of transmembrane spanning regions in the protein (Krogh et al. 2001). The ProtComp program (version 9.0; http://www.softberry.com) was used to predict the subcellular localization of the protein.

Gene expression analyses by real-time PCR

RNA extraction and cDNA synthesis Leaf disks $\left(1.77 \mathrm{~cm}^{2}\right)$ were collected from the inoculated leaflets described above at each inoculation spot immediately after inoculation and then one, two, five and nine days post-inoculation. The controls were fragments from leaves inoculated with water supplemented with $0.02 \%$ Tween 20 . For each time point, three sets of inoculated fragments were analyzed independently (three biological replicates). Collected samples were lyophilized and stored at $-20{ }^{\circ} \mathrm{C}$. The total RNA was extracted from the samples using CTAB extraction buffer (Chang et al. 1993), treated with RNase-free RQ1 DNase (Promega), quantified by spectrophotometry and quality tested by electrophoresis on $1.2 \%$ agarose gels. The firststrand cDNA was synthesized from $1 \mu \mathrm{g}$ of total RNA using oligodT and SuperScript III (Invitrogen) according to the supplier's protocol.

Design of Cas-specific primers Several pairs of primers were designed from the sequence of each Cas gene homologue, including at least one primer that overlapped an intron site. Their efficiency was tested on diluted cDNA pools of all time points for each isolate by cultivar set. The specificity of the amplification was analyzed using the melting temperature curves at the end of each run. The best primer pairs were selected for the real-time RT-PCR experiments. The primers selected to amplify the Cas 1 transcripts were CasF12 and Cc-qCas1-R2. For Cas 3 and Cas 4 transcripts, the primers selected were $\mathrm{Cc}-\mathrm{qCas} 3,4-\mathrm{F} 1$ and $\mathrm{Cc}$ qCas3,4-R1. A third primer pair (Cc-qCas1,3,4-F1/CcqCas1,3,4-R1) designed to amplify conserved regions of all Cas homologue cDNA sequences was used as a positive control. All of these primer pairs failed to amplify any product from cDNA derived from non-inoculated leaves. Primer sequences are listed in the Electronic Supplementary Material (ESM 2).

Design of C. cassiicola-specific reference gene primers Primers were designed based on conserved regions (framing one intron site) determined from the alignment of EF1 $\alpha$ or actin gene sequences from various fungal species, most of which belonged to the order Pleosporales, like C. cassiicola. Primers designed from the $E F 1 \alpha$ sequences were Nc$\mathrm{EF} 1 \alpha-\mathrm{F} 2$ and $\mathrm{Cc}-\mathrm{EF} 1 \alpha-\mathrm{R} 1$. Primers designed from the actin sequences were Cc-Actin-F4 and Cc-Actin-R1. These primers were used to amplify partial genomic sequences from all of the $C$. cassiicola isolates from this study. The PCR products were sequenced as described above and compared by multiple sequence alignment. New primers were designed for real-time RT-PCR, with the forward primer overlapping the intron. For EF1 $\alpha$, two forward primers were designed depending on the isolate due to a one-nucleotide substitution in the primer binding site. Primer Cc-qEF1 $\alpha-\mathrm{F} 1$ was developed for isolates $\mathrm{CCP}, \mathrm{E} 78$, and $\mathrm{E} 70$ and primer $\mathrm{Cc}-\mathrm{qEF} 1 \alpha-\mathrm{F} 3$ was developed for isolates E79 and E139. The reverse primer, $\mathrm{Cc}-\mathrm{qEF} 1 \alpha-\mathrm{R} 1$, was the same for all isolates. For the actin gene, the primers designed were Cc-qActin-F2 and Cc-qActin-R2. The actin gene was used as a reference to validate the stability of the EFI $\alpha$ gene expression over the course of the infection (data not shown). The EF1 $\alpha$ gene was used as a reference for the quantification of Cas gene expression. Primer sequences are listed in the Electronic Supplementary Material (ESM 2).

Quantification of the cassiicolin homolog transcripts by real-time RT-PCR Amplifications were performed using an iCycler IQ (Bio-Rad) with SYBR green as the fluorescent dye. The PCR reaction mix $(25 \mu \mathrm{l})$ contained cDNA $(2 \mu \mathrm{l}$ of a $1 / 50$ dilution of the first strand cDNA), $1 \times$ Mesa Green qPCR MasterMix Plus for SYBR Assay W/ fluorescein (Eurogentec, Angers, France) and $200 \mathrm{nM}$ of each primer. Polymerase chain reactions were performed as follows: $3 \mathrm{~min}$ at $95{ }^{\circ} \mathrm{C}$ for denaturation and amplification for 40 cycles $\left(10 \mathrm{~s}\right.$ at $95{ }^{\circ} \mathrm{C}, 15 \mathrm{~s}$ at $62{ }^{\circ} \mathrm{C}, 15 \mathrm{~s}$ at $72{ }^{\circ} \mathrm{C}$ ). The relative quantitative abundance (Qr) of the Cas homologue transcripts was calculated by comparison with the expression of EFl $\alpha$ using the following formula 
(Pfaffl 2001), with E representing the primers' efficiency, "target" referring to the cassiicolin homologues and "ref" to $E F 1 \alpha$ :

$\mathrm{Qr}=\frac{\left(1+\mathrm{E}_{\text {target }}\right)^{\Delta \mathrm{Ct} \text { target }}}{\left(1+\mathrm{E}_{\text {ref }}\right)^{\Delta \mathrm{Ct} r e f}}$

The real-time PCR amplifications were performed in triplicate (technical replicates) and the experiment was repeated three times (biological replicates). Data presented are the mean \pm the standard error of the three independent biological replicates.

Monitoring of C. cassiicola development in lesions by realtime RT-PCR To analyze the development of the fungus in the plant tissues, the accumulation of transcripts of the $C$. cassiicola-specific EFI $\alpha$ gene was monitored and compared to the expression of a polyubiquitin gene from the rubber tree (Hb-polyubiquitin, unpublished results). The primers used to amplify $\mathrm{Hb}$-polyubiquitin transcripts were $\mathrm{Hb}-\mathrm{Ubi}$ F/Hb-Ubi-R (ESM 2). The composition of the real-time PCR mix and the program used for real-time PCR were the same as described above for the Cas homologues expression analysis, except for the annealing temperature $\left(57{ }^{\circ} \mathrm{C}\right)$. The level of rubber tree colonization by $C$. cassiicola was represented by the relative expression (Qr) of the fungal EF1 $\alpha$ gene normalized to the rubber tree Polyubiquitin transcript level.

\section{Statistical analyses}

Analyses of variance (ANOVA) were performed with software R, version 2.10.1 (R_Development_Core_Team 2009) and differences between means were tested using Tukey's Honest Significant Difference (HSD) test $(P<0.05)$. For real-time PCR, statistical analyses were performed on logtransformed data because empirical errors in Qr increased with $\mathrm{Qr}$ values consistent with the above exponential formulation.

\section{Results}

Diversity of the fungal endophytes

A total of 70 endophytic fungi were isolated from asymptomatic rubber tree leaves from a rubber plantation in Bahia, Brazil (ESM 1). The molecular identification based on ITS sequence similarity revealed that $100 \%$ of the isolates were filamentous Ascomycota. Five genera predominated of which, $49 \%$ of the isolates belonged to the genus Colletotrichum and its teleomorph Glomerella, $15 \%$ to the genus Phomopsis genus and its teleomorph Diaporthe, $13 \%$ to the genus Nigrospora, $7 \%$ to the genus Xylaria and $6 \%$ to the genus Corynespora. Other rare genera were also isolated, such as Guignardia (two strains) and Alternaria, Daldinia, Leptosphaerulina and Hypoxylon (one strain each).

The four Corynespora isolates were identified as cassiicola species, with at least $99.8 \%$ identity and $100 \%$ query coverage. C. cassicola isolates E78, E79 and E139 were recovered from rubber tree cultivar RRIM 600 and isolate E70 was recovered from FDR 5788. This is the first report of an endophytic $C$. cassiicola in a rubber tree in Brazil. This is of significance as CLF disease outbreaks have not been reported in rubber tree plantations in South America, although C. cassiicola affects many other plant species in the area.

Description of new cassiicolin genes from C. cassiicola endophytic strains

The presence of Cas gene homologues in all four C. cassiicola endophytic strains was determined by PCR using different primer pairs designed from Cas (EF667973), the reference cassiicolin gene cloned from the rubber tree pathogenic isolate CCP originating from the Philippines (Déon et al. 2012), and CT1 (GU373809), a Cas gene homologue from a Chinese rubber tree isolate (CC004). Partial sequences were successfully amplified. The fulllength sequence of the Cas gene homologues was obtained from all four isolates using the genome walking method. The new sequences were registered under the accession numbers JF915169, JF915170, JF915171 and JF915172 for isolates E70, E78, E79 and E139, respectively.

The nucleotide sequence alignment (ESM 3 and Fig. 1) revealed some diversity among the Cas gene homologues from the four endophytic strains, although they are closely related sequences. E79 and E139 Cas gene sequences were $100 \%$ identical, while E70 and E78 Cas gene sequences shared $99 \%$ identity with each other and 99 and $98 \%$ identity, respectively, with the E79/E139 Cas gene sequence. Isolates E70, E78 and E79/E139 shared $78 \%$, $78 \%$ and $79 \%$ identity, respectively, with the reference

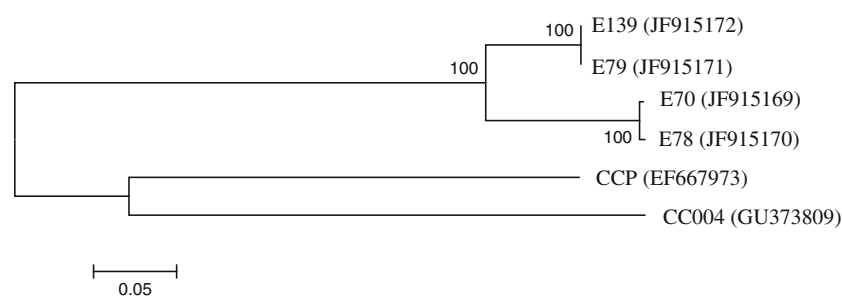

Fig. 1 Neighbor-joining phylogenetic tree of the cassiicolin precursor genes from four endophytic (E70, E78, E79 and E139) and two pathogenic strains of C. casiicolin (CCP and CC004). Bootstrap values are shown above the branch 
Cas gene and $78 \%$ identity with CT1. An alignment of the predicted amino acid sequences from all the Cas gene sequences revealed two new cassiicolin precursor proteins (Fig. 2). They were named Cas3 (protein id AFH88923 and AFH88924 from isolates E70 and E78 respectively) and Cas4 (protein id AFH88925 and AFH88926 from isolates E79 and E139 respectively), with Cas1 as the reference isoform (isolate CCP) and Cas2 as the protein encoded by CT1. Like Cas1, Cas3 and Cas4 are organized into an Nterminal domain including a 17 amino acid putative signal peptide followed by a 14 amino acid linker region and a 27 amino acid C-terminal domain corresponding to the putative mature protein. No transmembrane-spanning region was identified using the TMHMM program. An extracellular localization was predicted by Neural nets using the ProComp program, suggesting that the encoded protein may be secreted. Cas 3 and Cas 4 share $98 \%$ identity (100\% positive amino acids) with each other, with only one substitution at position 15 in the signal peptide. They share respectively $93 \%$ and $94 \%$ identity (98\% positive amino acids) with the reference Cas 1 sequence. The predicted mature cassiicolin domain shows one positive substitution ( $\mathrm{S}$ instead of $\mathrm{T}$ ) compared to the reference Cas1 sequence. Cas 2 remains the most divergent protein isoform with seven substitutions and one insertion relative to Cas1, as described previously (Déon et al. 2012).

The $5^{\prime}$ and $3^{\prime}$ untranslated regions as well as the introns were the more divergent regions in the cas gene sequences. The ratio between the non-synonymous $\left(d_{N}\right)$ and synonymous $\left(d_{S}\right)$ substitution rates was calculated for each sequence pair to estimate the selection pressure acting on the cas gene. This ratio could not be calculated among the $C$. cassiicola endophytes since a single divergent nucleotide only was observed in their coding region. The $d_{N} / d_{S}$ ratios calculated between the cas gene sequences from the isolates $\mathrm{CCP}, \mathrm{CC} 004$ and the endophytes were all $<1$ (between 0.13 and 0.34 ) suggesting that the Cas gene may be under purifying selection pressure.

\section{Pathogenicity of the C. cassiicola endophytes}

Inoculations on detached leaves were performed to investigate the potential pathogenicity of the four $C$. cassiicola endophytic isolates on the cultivars from which they were originally isolated (Fig. 3). The pathogenic strain CCP was used as a control on both cultivars. The water controls remained negative over the whole experiment. No necrosis was observed at 1 and 2 days post-inoculation (dpi) regardless of the isolate. At $5 \mathrm{dpi}$, only pinpoint necroses were visible on the leaves inoculated with the endophytic strains E78, E79 and E139 isolated from the RRIM600 cultivar. However, plants inoculated with the pathogenic isolate CCP had already developed disease symptoms at this time as lesion size had reached $445 \mathrm{~mm}^{2}$. At 9 dpi, differences between isolates were evident and the pathogenic strain CCP was the most aggressive, followed by the endophytes E139 and E79. E78 remained under the virulence threshold (pinpoint necroses only). There was no significant difference in lesion size $(P<0.05)$ between the endophytic isolate E70 and the pathogenic isolate CCP on cultivar FDR 5788, with significant symptoms present at $5 \mathrm{dpi}$, which dramatically increased by 9 dpi.

Kinetics of mycelium development in the leaf tissues post-inoculation

The amount of mycelium that colonized rubber tree leaf tissue, post-inoculation was quantified by real-time PCR by calculating the relative expression $(\mathrm{Qr})$ of a $C$. cassiicola-specific EFla gene normalized to a rubber tree-specific polyubiquitin gene 1, 2, 5 and 9 dpi (Fig. 4). In the RRIM 600 cultivar (Fig. 4a), EFla relative expression (Qr) was already detectable 1 and 2 dpi for E139 and CCP, while it was very low (nearly undetectable) for the other strains, suggesting that colonization of mycelia for these two strains started earlier, which is in agreement with their higher aggressiveness compared to E78 and E79. The Qr increased and reached a maximal level at $9 \mathrm{dpi}$, which was similar for both E139 and CCP. The development of E79 mycelium started later (between 2 dpi and $5 \mathrm{dpi}$ ) but finally reached levels similar to those of E139 and CCP at 5 and 9 dpi. In contrast, E78 mycelium colonization remained very low even at 9 dpi. In the FDR 5788 cultivar (Fig. 4b), the mycelium growth of both CCP and E70 was detectable as early as $1 \mathrm{dpi}$ and strongly increased over time. Both strains presented similar profiles at 2, 5 and $9 \mathrm{dpi}$, although the mycelial growth may have started earlier for E70 than CCP.

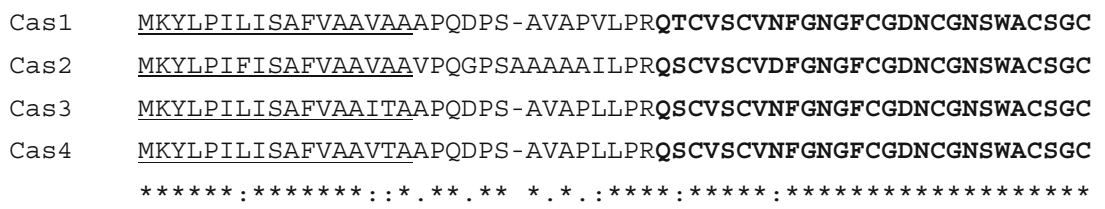

Fig. 2 The amino acids sequence alignment of the cassiicolin precursor proteins Cas1 (ABV25895), Cas2 (ADC54229), Cas3 (AFH88923 and AFH88924) and Cas4 (AFH88925 and AFH88926). The mature cassiicolin domain is indicated by bold letters. The signal peptide is

underlined. CLUSTAL W annotation: conserved amino acids (*); amino acids of strongly similar properties (:); amino acids of weakly similar properties (.) 
Fig. 3 Pathogenicity of four endophytic C. cassiicola isolates in a detached-leaf assay under controlled conditions. Isolates were inoculated onto the detached leaves of their respective original host rubber tree cultivar and pathogenic CCP strain was used as a control for both cultivars. For each isolate, six leaves were inoculated, each with ten drops of conidia suspension and one drop of water as untreated control. The lesion area per leave was measured manually, at 5 and 9 dpi. The entire experiment was conducted three times. Panel a: Symptoms Intensity expressed as the mean lesion area \pm the standard error from the 18 inoculated leaves. For each cultivar, values followed by the same letter were not significantly different, according to Tukey's HSD test $(P<0.05)$. Panel b: Visual symptoms
A

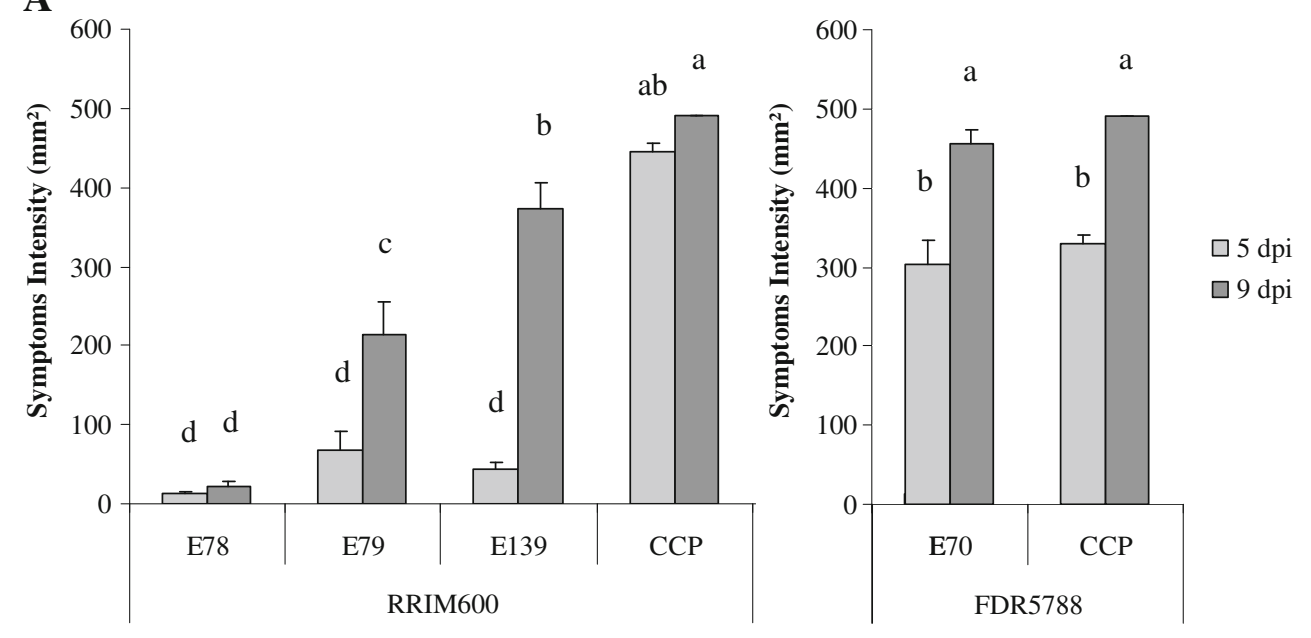

B

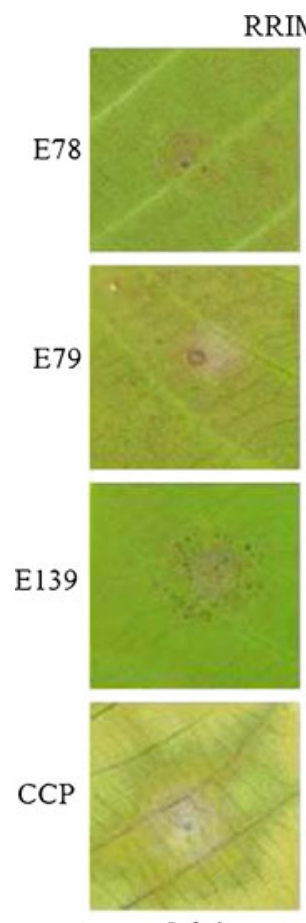

RRIM600

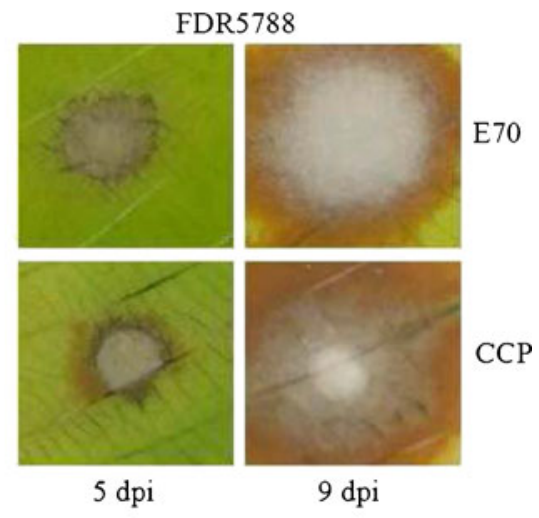

$\overline{6,3 \mathrm{~mm}}$
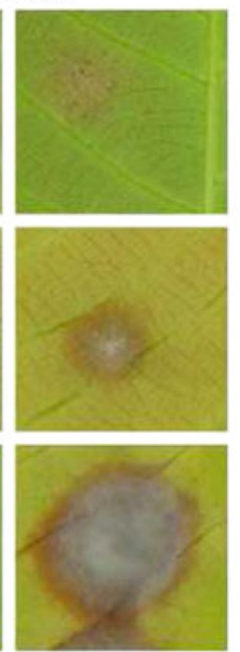

9 dpi

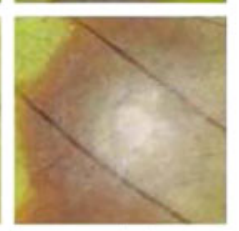

9 dpi
Kinetics of Cas gene homologues expression post-inoculation

The relative expression level of the Cas 1, Cas 3 and Cas 4 genes was determined at 1, 2, 5 and 9 dpi. Only Cas 1 from isolate CCP was expressed in RRIM 600 and FDR 5788 cultivars (Fig. 5). No Cas 3 or 4 transcripts were detected post-inoculation at any time point for any of the endophytic isolates. The Cas 1 expression profile in RRIM 600 was as expected based on previous analyses (Déon et al. 2012), with a transient peak of expression at 2 dpi. In FDR 5788, no peak of expression was observed and the Cas 1 relative expression remained similarly low at all time points.

\section{Discussion}

Diversity of the fungal endophytes in Hevea brasiliensis

There are still only a few studies investigating endophytic fungi in Hevea brasiliensis. The largest analysis was performed on wild rubber trees from Peru and compared the diversity of endophytic fungi in leaves and sapwood (Gazis and Chaverri 2010). A second study was conducted on cultivated rubber trees from rubber plantations in Bahia, Brazil with the objective of identifying antagonists to Microcyclus ulei, another fungal pathogen of the rubber tree (Rocha et al. 2011). In our study, as in the study by Rocha et 
Fig. 4 Colonization of $C$. cassiicola mycelia in rubber tree leaf tissues post-inoculation measured by real-time PCR. The kinetics of $C$. cassiicola mycelia growth at 1,2,5 and 9 days post inoculation of the (a) RRIM 600 cultivar and (b) FDR 5788 cultivar were quantified by calculating the relative expression (Qr) of a C. cassiicola-specific $E F 1 \alpha$ gene normalized to a rubber tree-specific polyubiquitin gene. Data presented are means \pm standard error of three independent replicates. Values followed by the same letter were not significantly different according to Tukey's HSD test $(P<0.05)$
A
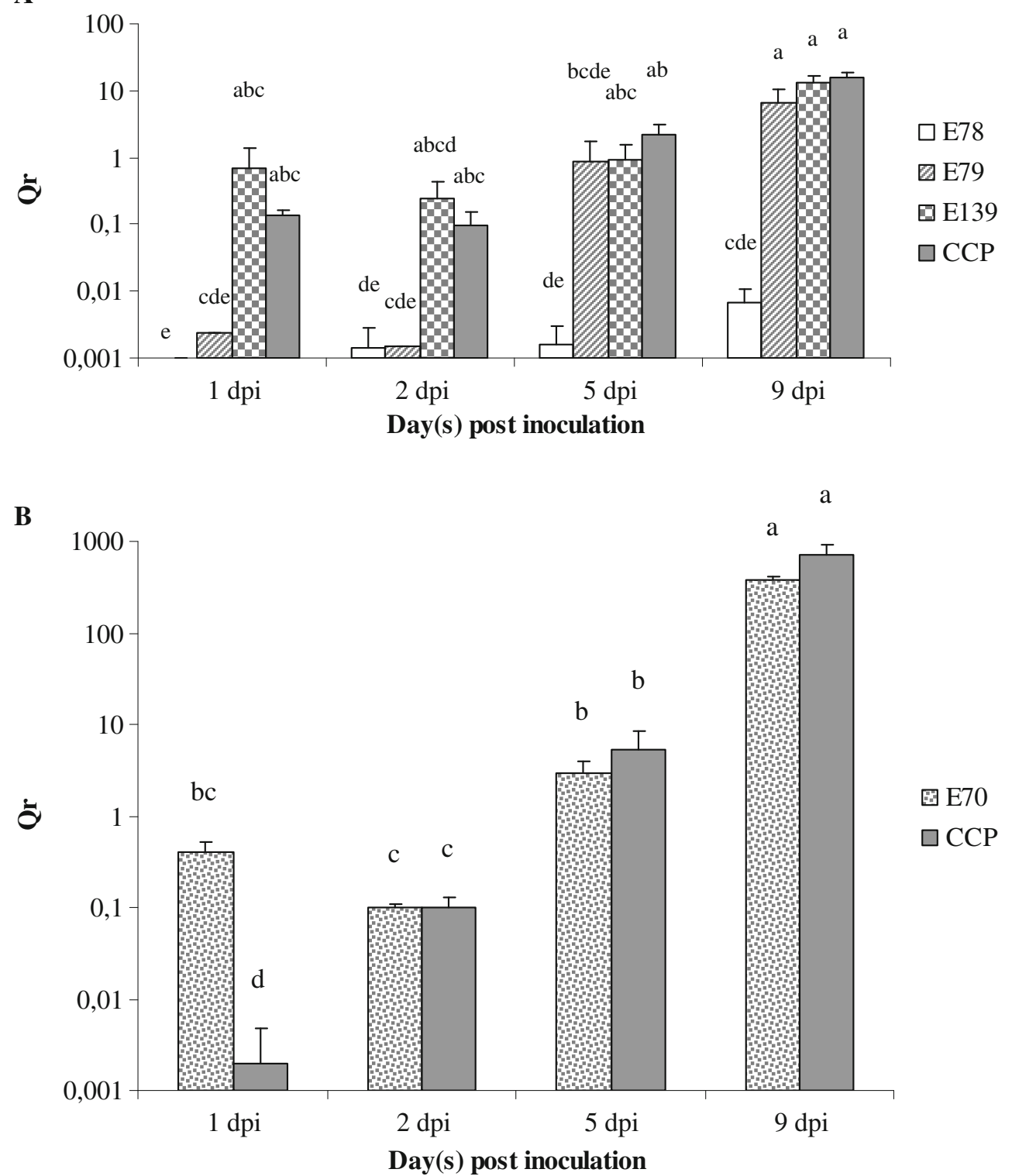

al., all of the isolates identified were Ascomycetes. Gazis and Chaverri (2010) found that Ascomycetes were dominant (97\% of the isolates), but Zygomycota and Basidiomycota were also represented ( $2 \%$ and $1 \%$, respectively), in agreement with the hypothesis that biodiversity is more important in the wild than in plantations. However, the identity and prevalence of the various isolated species varied among these three studies. In our study, the dominant genera were Colletotrichum (49\%), Phomopsis (15\%) and Nigrospora (13\%). Among these genera, only Colletotrichum and Phomopsis were found in all three studies. In the populations isolated from wild rubber trees from Peru (Gazis and Chaverri 2010), Pestalotiopsis, Trichoderma and Penicillium genera predominated ( $23 \%, 22 \%$ and $18 \%$ of all isolates). Surprisingly, none of these genera were isolated in the course of this study or by Rocha et al. (2011). This could be explained by the difference in geographical origin or cultivation history of the rubber trees. Gazis and Chaverri (2010) sampled wild rubber trees from the most biodiverse and undisturbed area of the world (Gazis and Chaverri 2010), while our study and Rocha et al. (2011) sampled rubber trees from plantations where biodiversity is clearly less important than in the forest. It should be underlined that Rocha et al. (2011) only provided molecular identification for the strains antagonistic to Microcyclus ulei, the causative agent of South American Leaf Blight (SALB), thus giving a partial representation of the endophyte population in the sampled trees. Nevertheless, three genera, Fusarium/Gibberella, Myrothecium, Pestalotiopsis/Pestalosphaeria and Microsphaeropsis/ Paraphaeosphaeria, identified by Rocha et al. (2011) were not represented among our isolates even though the samples had the same origin of a rubber plantation in Bahia. The 
Fig. 5 Real-time PCR analysis of Cas gene expression 1, 2, 5 and 9 days post-inoculation onto the (a) RRIM 600 cultivar and (b) FDR 5788 cultivar. Data presented are means \pm the standard error of three independent replicates. Values followed by the same letter were not significantly different according to Tukey's HSD test $(P<0.05)$
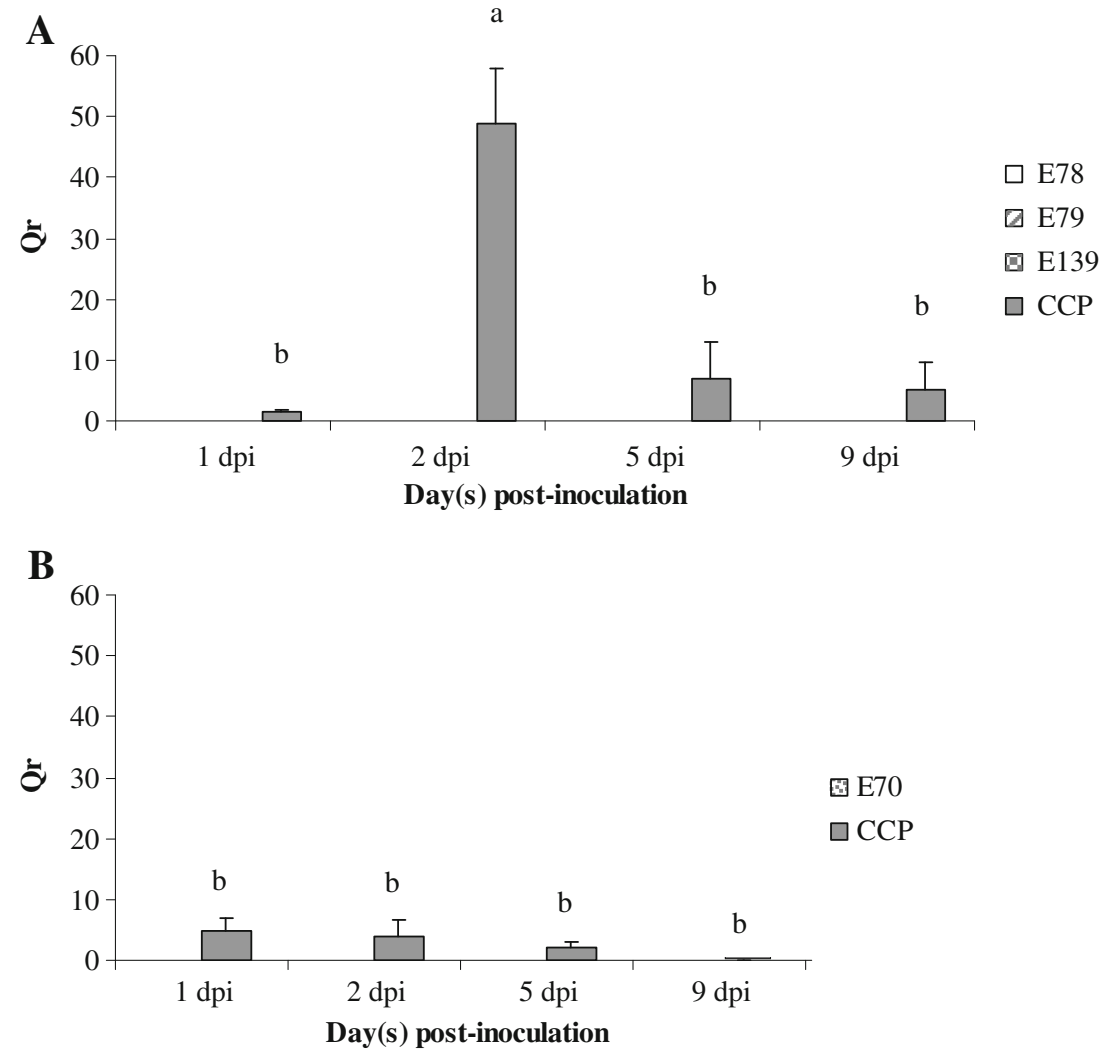

physiological state of the leaves from which the endophytes were isolated, i.e. dry versus fresh leaves, could certainly have influenced the diversity of the recovered endophytic population. Among the specific genera that we found compared to Rocha et al. 2011, several species are known to degrade wood, such as Xylaria sp. or Hypoxylon sp. (Chaparro et al. 2009). This suggested that our study was selective for species associated with senescent plant material. Supporting this hypothesis, Promputtha et al. (2002) showed that the stage of leaf decomposition in Magnolia liliifera had an important impact on the diversity of endophyte populations.

An important result of our study is the identification of four $C$. cassiicola isolates. This is the first report of endophytic C. cassiicola in Hevea brasiliensis. C. cassiicola is primarily known as a pathogen affecting more than 300 plant species (http://nt.ars-grin.gov/fungaldatabases/ (Farr and Rossman 2011)). However, C. cassiicola was also reported as an endophyte of Quercus ilex (Collado et al. 1999), Aegle marmelos (Gond et al. 2007), Magnolia liliifera (Promputtha et al. 2007) and several other trees from tropical forests (Suryanarayanan et al. 2011). The fungus has also been observed as a saprotroph on cucumbers, tomatoes, papaya (Kingsland 1985), Bambusa spp. and Dendrocalamus spp. (Hyde et al. 2001), Ischyrolepis subverticella (Lee et al. 2004) and Magnolia liliifera (Promputtha et al. 2007, 2010; Kodsueb et al. 2008).
However, many other plants can support C. cassiicola growth as a pathogen, endophyte or saprotroph (Dixon et al. 2009). Our results demonstrate that, even though outbreaks of CLF disease have not yet occurred in South America, C. cassiicola is present in rubber trees on the American continent.

Are endophytic $C$. cassiicola isolates latent pathogens or latent saprotrophs?

Many species known to cause disease in plants are regularly isolated from asymptomatic tissues and are therefore also classified as endophytes (Kumar and Hyde 2004; Photita et al. 2004, 2005). Whether these are different subspecies or the same strain able to switch from one lifestyle to another is usually unknown. In the case of cacao (Rojas et al. 2010), haplotype subgroups were distinguished among Colletotrichum gloeosporioides isolates that were preferentially associated with either symptomatic or asymptomatic interactions. However, the isolates collected from asymptomatic tissues were not tested for pathogenicity. In several cases, endophytes inoculated onto their host plant under controlled conditions were found to be pathogenic (Mostert et al. 2000; Photita et al. 2004; Lana et al. 2011). With regard to C. cassiicola, Dixon et al. (2009) 
showed that all isolates collected from healthy tissue of different plant species were pathogenic to the original host.

We inoculated four endophytic C. cassiicola onto detached leaves from their original host cultivar under controlled conditions. The strain E70 isolated from the FDR 5788 rubber tree cultivar induced symptoms when inoculated on the same cultivar, with virulence (Fig. 3) and mycelia colonization (Fig. 4) profiles similar to that of the pathogenic strain CCP. We may therefore wonder whether this endophytic $C$. cassiicola strain is a latent pathogen. This would be very worrying considering that rubber trees were so far spared from the CLF disease in this area. However, these experiments were conducted on detached leaves kept alive under moist environment for up to nine days, which cannot reflect exactly the field conditions. The initiation of the senescence process may have induced a lifestyle transition from endophyte to pathogen, in agreement with previous works showing that some endophytes may become pathogenic when the host plant is stressed (Fisher and Petrini 1992). However, a more probable interpretation would be that the observed symptoms reflect a saprotrophic process rather than parasitism.

Several studies proposed that fungal endophytes become saprotrophs when the host plants senesce (Promputtha et al. 2007, 2010; Okane et al. 2008; Porras-Alfaro and Bayman 2008). The close phylogenetic relationships between endophytes and saprotrophs isolated from healthy, mature and decaying leaves and twigs of Magnolia liliifera, including C. cassiicola isolates, suggest that these fungi have the ability to change their lifestyle during host senescence (Promputtha et al. 2007). This supports the concept of latent saprotrophism. Promputtha et al. (2010) demonstrated that a C. cassiicola endophyte and its saprobic counterpart, which was found during the middle to late stages (8-56 days) of leaf decomposition, were both able to produce laccase. The authors hypothesized that laccase activity from the C. cassiicola endophyte allows it to persist as a saprobe during decomposition.

In our study, the $C$. cassiicola strains isolated from asymptomatic rubber tree leaves were inoculated onto detached leaves from their original host cultivar, and the symptoms (necrotic surface area) and mycelium development were measured at various time-points from 1 to 9 days post-inoculation (dpi). This long kinetic revealed different phenotypes among the various isolates and suggested a possible switch from an endotrophic to a saprotrophic lifestyle. Indeed, the three endophytic isolates inoculated on RRIM 600 leaves were still under the virulence threshold at 5 dpi (the pathogenic strain had already induced significant symptoms at this time), but at $9 \mathrm{dpi}$, two of these isolates (E79 and E139) finally induced symptoms with significant mycelium development. It is possible that senescence-associated modifications of the leaf tissue enabled the penetration of the mycelium inside the host cells and the saprotrophic development of these strains. It should be noted that some mycelium development could be detected by real-time RT-PCR prior to any visible necrotic symptom, as early as $1 \mathrm{dpi}$ in case of E139, E70 and CCP. We suspect that these isolates may have a phase of epiphytic development before the mycelium penetrates through the cells upon toxin action (necrotrophy) or senescence-induced alteration of the tissues (saprotrophy). In the case of the isolate E78, which remained avirulent even at 9 dpi, we cannot rule out all saprobic activity but the very low amount of mycelium detected at 5 and 9 dpi demonstrated that it is clearly less competitive than the other isolates in senescing tissue.

Discovery of new cassiicolin gene homologues

New cassiicolin gene homologues potentially encoding two new cassiicolin precursor protein isoforms (Cas3 and Cas4) were found in the endophytic $C$. cassiicola isolates. Their predicted amino acid sequence is similar to that of the Cas 1 reference isoform. In particular, the mature cassiicolin domain is highly conserved, with only one amino acid substitution ( $\mathrm{S}$ instead of $\mathrm{T}$ ) at position 2. This amino acid is especially important because it carries the sugar moiety ( 0 methyl-mannose) of the active cassiicolin (Barthe et al. 2007; de Lamotte et al. 2007). Although the role played by this sugar in toxicity is still unknown, it should be noted that Serine (S), like Threonine (T), can be 0-glycosylated. Therefore, the glycosylation of the toxin is not jeopardized by the $\mathrm{T}$ to $\mathrm{S}$ substitution.

The cassiicolin gene may be under purifying selection pressure, as indicated by the low $(<1) d_{N} / d_{S}$ ratios. This suggests that this gene is playing and important functional role in C. cassiicola. However, this will have to be confirmed when a higher number of $C a s$ gene sequences reflecting C. cassiicola evolution history will be available.

Although the genes encoding Cas 3 and Cas 4 appear structurally functional, no Cas 3 and Cas 4 transcripts could be detected post-inoculation. Therefore, if Cas 3 and Cas 4 genes are functional, it seems that their transcription is negatively controlled under the conditions used in this experiment. We have previously shown (Déon et al. 2012) that Cas 1 is transiently expressed, with a sharp peak of expression at 1 or 2 dpi depending on the cultivar. This was confirmed in this work for RRIM 600 inoculated with CCP. In the cultivar FDR 5788 inoculated with CCP, Cas 1 was expressed, but no peak of expression was observed. We suggest that the peak may have occurred at a different timepoint not tested in this experiment. Whether Cas 3 and 4 can be switched on and under which conditions is unknown. In our analysis, some of the endophytic isolates induced necrosis on detached leaves five or nine days post-inoculation, although the corresponding Cas genes were not expressed, 
suggesting that symptoms under these specific conditions are not mediated by the Cas 3 or Cas 4 proteins. This supports the idea that $C$. cassiicola can penetrate senescing tissues without the support of the Cas toxin and develop as a saprobe. The exact role of cassiicolin in the early phase of development and its ability to cause disease in intact plants needs to be further explored, over short time scales post inoculation.

\section{Conclusion}

In this work, we demonstrated that $C$. cassiicola is present in rubber plantations in Brazil in an endophytic form. Among the four isolates found, three were able to induce disease symptoms in a detached-leaf assay using rubber tree leaves under controlled conditions. This could be the manifestation of a saprotrophic lifestyle, although a pathogenic ability is not excluded, at least for one of the isolates. Whatsoever, our results suggest that the new Cas gene homologues identified in these isolates were not involved under the conditions used in this study. C. cassiicola affects many other plants in Brazil. It is possible that cassiicolin gene homologues play a role in other hosts and that their expression requires specific host plant signals. Rubber trees may serve as inoculum reservoir for these plants. Further studies conducted on whole plants are necessary to understand which parameters control C. cassiicola development and lifestyle. Potential antagonistic effects from other microorganisms should also be considered. The fungal endophytes isolated in this study in parallel with $C$. cassiicola are good candidates for antagonists to C. cassiicola. The exact role of cassiicolin and other potential effectors in the interaction between $C$. cassiicola and the rubber tree should also be investigated further.

Acknowledgements This work was supported in part by a grant from the IFC (Institut Français du Caoutchouc, Paris, France) and the companies Michelin (Clermont-Ferrand, France), SIPH ("Société Internationale de Plantations d'Hévéas", Courbevoie, France) and SOCFIN ("Société Financière des Caoutchoucs", Bruxelles, Belgium). We thank Boris Fumanal and Jean-Stéphane Vénisse for their valuable comments.

Open Access This article is distributed under the terms of the Creative Commons Attribution License which permits any use, distribution, and reproduction in any medium, provided the original author(s) and the source are credited.

\section{References}

Atan S, Hamid NH (2003) Differentiating races of Corynespora cassiicola using RAPD and internal transcribed spacer markers. J Rubber Res 6(1):58-64

Barthe P, Pujade-Renaud V, Breton F, Gargani D, Thai R, Roumestand C, de Lamotte F (2007) Structural analysis of cassiicolin, a host- selective protein toxin from Corynespora cassiicola. J Mol Biol 367(1):89-101

Bendtsen JD, Nielsen H, von Heijne G, Brunak S (2004) Improved prediction of signal peptides: Signalp 3.0. J Mol Biol 340(4):783-795

Breton F, Sanier C, d'Auzac J (2000) Role of cassiicolin, a host-selective toxin, in pathogenicity of Corynespora cassiicola, causal agent of a leaf fall disease of Hevea. J Rubber Res 3(2):115-128

Cai L, Ji K-F, Hyde K (2006) Variation between freshwater and terrestrial fungal communities on decaying bamboo culms. Antonie van Leeuwenhoek 89(2):293-301. doi:10.1007/s10482005-9030-1

Chang S, Puryear J, Cairney J (1993) A simple and efficient method for isolating RNA from pine trees. Plant Mol Biol Rep 11(2):113-116

Chaparro DF, Rosas DC, Varela A (2009) Isolation of wood-decaying fungi and evaluation of their enzymatic activity (Quindio, Colombia). Rev Iberoam Micol 26(4):238-243

Chee KH (1988) Studies on sporulation, pathogenicity and epidemiology of Corynespora cassiicola on hevea rubber. J Nat Rubber Res 3:21-29

Chee KH (1990) Rubber diseases and their control. Rev Plant Pathol 69(7):423-430

Collado J, Platas G, Gonzalez I, Pelaez F (1999) Geographical and seasonal influences on the distribution of fungal endophytes in Quercus ilex. New Phytol 144(3):525-532

Darmono TW, Darussamin A, Pawirosoemardjo S (1996) Variation among isolates of Corynespora cassiicola associated with Hevea brasiliensis in Indonesia. In: Proceeding workshop on Corynespora leaf fall disease of Hevea rubber. Medan, Indonesia, 16-17 December, pp 79-91

de Lamotte F, Duviau MP, Sanier C, Thai R, Poncet J, Bieysse D, Breton F, Pujade-Renaud V (2007) Purification and characterization of cassiicolin, the toxin produced by Corynespora cassiicola, causal agent of the leaf fall disease of rubber tree. J Chromatogr B 849(1-2):357-362

Déon M, Bourré Y, Gimenez S, Berger A, Bieysse D, de Lamotte F, Poncet J, Roussel V, Bonnot F, Oliver G, Franchel J, Seguin M, Leroy T, Roeckel-Drevet P, Pujade-Renaud V (2012) Characterization of a cassiicolin-encoding gene from Corynespora cassiicola, pathogen of rubber tree (Hevea brasiliensis). Plant Sci 185-186:227-237. doi:10.1016/ j.plantsci.2011.10.017

Dixon LJ, Schlub RL, Pernezny K, Datnoff LE (2009) Host specialization and phylogenetic diversity of Corynespora cassiicola. Phytopathology 99(9):1015-1027. doi:10.1094/ PHYTO-99-9-1015

Drummond AJ, Ashton B, Buxton S, Cheung M, Cooper A, Duran C, Field M, Heled J, Kearse M, Markowitz S, Moir R, Stones-Havas S, Sturrock S, Thierer T, Wilson A (2011) Geneious v5.4, available from http://www.geneious.com/

Farr DF, Rossman AY (2011) Fungal Databases. Systematic Mycology and Microbiology Laboratory, ARS, USDA, from/ fungaldatabases/

Felsenstein J (1985) Confidence limits on phylogenies: an approach using the bootstrap. Evolution 39:783-791

Fisher PJ, Petrini O (1992) Fungal saprobes and pathogens as endophytes of rice (Oryza sativa L.). New Phytol 120:137-143

Gazis R, Chaverri P (2010) Diversity of fungal endophytes in leaves and stems of wild rubber trees (Hevea brasiliensis) in Peru. Fungal Ecol 3(3):240-254

Goldman N, Yang Z (1994) A codon-based model of nucleotide substitution for protein-coding DNA sequences. Biol Evol 11:725-736

Gond SK, Verma VC, Kumar A, Kumar V, Kharwar RN (2007) Study of endophytic fungal community from different parts of Aegle marmelos Correae (Rutaceae) from Varanasi (India). World J Microbiol Biotechnol 23:1371-1375 
Hallé F, Martin R (1968) Etude de la croissance rythmique chez l'hévéa (Hevea brasiliensis) (Müll. Arg., Euphorbiacées, crotonoïdées). Adansonia 8:475-503

Hyde KD, Ho WH, McKenzie EHC, Dalisay T (2001) Saprobic fungi on bamboo culms. Fungal Divers 7:35-48

Jayasinghe CK, Silva WPK (1996) Current status of Corynespora leaf fall in Sri Lanka. In: Proceeding on the Workshop on Corynespora Leaf Fall Disease, Medan, Indonesia, pp 3-5

Jayasinghe CK, Silva WPK, Wettasinghe DS (1998) Corynespora cassiicola: a fungal pathogen with diverse symptoms on Hevea rubber. Bull Rubber Res Inst Sri Lanka 39:1-5

Junqueira NTV, Gasparotto L, Moraes VHF, Silva HM, Lim TM (1985) New diseases caused by virus, fungi and also bacterium on rubber from Brazil and their impact on international quarantine. In: Proceeding of the regional conference on plant quarantine support for agricultural development, Kuala Lumpur, Malaysia, 10-12 December, pp 253-260

Kingsland GC (1985) Pathogenicity and epidemiology of Corynespora cassiicola in the Republic of the Seychelles. Acta Hortic (ISHS) 153:229-230

Kodsueb R, MacKenzie EHC, Lumyong S, Hyde KD (2008) Diversity of saprobic fungi on Magnoliaceae. Fungal Divers 30:37-53

Koenning SR, Creswell TC, Dunphy EJ, Sikora EJ, Mueller JD (2006) Increased occurrence of target spot of soybean caused by Corynespora cassiicola in the Southeastern United States. Plant Dis 90(7):974. doi:10.1094/PD-90-0974C

Krogh A, Larsson B, von Heijne G, Sonnhammer ELL (2001) Predicting transmembrane protein topology with a hidden Markov model: application to complete genomes. J Mol Biol 305:567-580

Kumar D, Hyde K (2004) Biodiversity and tissue-recurrence of endophytic fungi in Tripterygium wilfordii. Fungal Divers 17:69-90

Lana T, Azevedo J, Pomella A, Monteiro R, Silva C, Araujo W (2011) Endophytic and pathogenic isolates of the cacao fungal pathogen Moniliophthora perniciosa (Tricholomataceae) are distinguishable based on genetic and physiological analysis. Genet Mol Res 10(1):326-334

Lee S, Melnik V, Taylor J, Crous P (2004) Diversity of saprobic hyphomycetes on Proteaceae and Restionaceae from South Africa. Fungal Divers 17:91-114

Liyanage NIS, Liyanage AS (1986) A study on the production of toxin in Corynespora cassiicola. J Rubber Res Inst Sri Lanka 65:51-53

Liyanage AS, Jayasinghe CK, Liyanage NIS, Jayaratne AHR (1986) Corynespora Leaf spot disease of rubber (Hevea brasiliensis) - a new report. J Rubber Res Inst Sri Lanka 65:47-50

Mostert L, Crous PW, Petrini O (2000) Endophytic fungi associated with shoots and leaves of Vitis vinifera, with specific reference to the Phomopsis viticola complex. Sydowia 52(1):46-58

Nei M, Kumar S (2000) Molecular evolution and phylogenetics. Oxford University Press, New York

Newsam A (1960) Plant Pathology Division Report. Rubber Research Institute of Malaysia

Nugawela A, Liyanage NIS, Liyanage AS, Aluthhewage RK (1989) Influence of infection by Corynespora cassiicola on carbon dioxide assimilation rate in Hevea leaves. J Nat Rubber Res 4 (4):233-238

Okane I, Srikitikulchai P, Toyama K, Læssøe T, Sivichai S, HywelJones N, Nakagiri A, Potacharoen W, Suzuki K-I (2008) Study of endophytic Xylariaceae in Thailand: diversity and taxonomy inferred from rDNA sequence analyses with saprobes forming fruit bodies in the field. Mycoscience 49(6):359-372. doi:10.1007/ s10267-008-0440-6

Oliveira RR, Vida JB, Tessmann DJ, Aguiar BM, Caixeta MP (2006) Reaçao de hibridos de pepino para cultivo protegido a isolados de Corynespora cassiicola. Fitopatol Bras 31:509-512
Oliveira RR, Vida JB, Tessmann DJ, BdM A, Caixeta MP, Barboza AL (2007) Patogenicidade de isolados de Corynespora cassiicola a diferentes espécies de plantas. Summa Phytopathol 33:297-299

Onesirosan P, Mabuni CT, Durbin RD, Morin RB, Righ DH, Arny DC (1975) Toxin production by Corynespora cassiicola. Physiol Plant Pathol 5:289-295

Pfaffl MW (2001) A new mathematical model for relative quantification in real-time RT-PCR. Nucleic Acids Res 29:e45

Photita W, Lumyong S, Lumyong P, McKenzie EHC (2004) Are some endophytes of Musa acuminata latent pathogens? Fungal Divers 16:131-140

Photita W, Taylor P, Ford R, Hyde K, Lumyong S (2005) Morphological and molecular characterization of Colletotrichum species from herbaceous plants in thailand. Fungal Divers 18:117-133

Pongthep K (1987) Corynespora disease of Hevea in Thailand. In: Proceedings of the IRRDB Symposium. Chiang Mai, Thailand, 2-3rd Nov, pp 1-17

Porras-Alfaro A, Bayman P (2008) Hidden fungi, emergent properties: endophytes and microbiomes. Annu Rev Phytopathol 49(1):291315. doi:10.1146/annurev-phyto-080508-081831

Promputtha I, Lymyong S, Lumyong P, McKenzie EHC, Hyde KD (2002) Fungal succession of senescent leaves of Manglietia garrettii in Doi Suthep-Pui National Park, northern Thailand. Fungal Divers 10:89-100

Promputtha I, Lumyong S, Dhanasekaran V, McKenzie EH, Hyde KD, Jeewon R (2007) A phylogenetic evaluation of whether endophytes become saprotrophs at host senescence. Microb Ecol 53(4):579-590

Promputtha I, Hyde K, McKenzie E, Peberdy J, Lumyong S (2010) Can leaf degrading enzymes provide evidence that endophytic fungi becoming saprobes? Fungal Divers 41(1):89-99. doi:10.1007/s13225-010-0024-6

Purwantara A (1987) A histological study of hevea leaves infected by Corynespora cassiicola. Menara Perkebunan 55:47-49

Qi Y, Xie Y, Zhang X, Pu J, Zhang H, Huang S, Zhang H (2009) Molecular and pathogenic variation identified among isolates of Corynespora cassiicola. Mol Biotechnol 41(2):145-151

R_Development_Core_Team (2009) R: a language and environment for statistical computing. R Foundation for Statistical Computing, Vienna

Risterucci AM, Grivet L, N'Goran JAK, Pieretti I, Flament MH, Lanaud C (2000) A high-density linkage map of Theobroma cacao L. Theor Appl Genet 101:948-955

Rocha ACS, Garcia D, Uetanabaro APT, Carneiro RTO, Araujo IS, Mattos CRR, Goes-Neto A (2011) Foliar endophytic fungi from Hevea brasiliensis and their antagonism on Microcyclus ulei. Fungal Divers 47:75-84

Rojas EI, Rehner SA, Samuels GJ, Van Bael SA, Herre EA, Cannon P, Chen R, Pang J, Wang R, Zhang Y, Peng Y-Q, Sha T (2010) Colletotrichum gloeosporioides s.l. associated with Theobroma cacao and other plants in Panama: multilocus phylogenies distinguish host-associated pathogens from asymptomatic endophytes. Mycologia 102(6):1318-1338. doi:10.3852/09-244

Romruensukharom P, Tragoonrung S, Vanavichit A, Toojinda T (2005) Genetic variability of Corynespora cassiicola population in Thailand. J Rubber Res 8(1):38-49

Saitou N, Nei M (1987) The neighbor-joining method: a new method for reconstructing phylogenetic trees. Mol Biol Evol 4:406-425

Sallaud C, Meynard D, van Boxtel J, Gay C, Bès M, Brizard JP, Larmande P, Ortega D, Raynal M, Portefaix M, Ouwerkerk PBF, Rueb S, Delseny M, Guiderdoni E (2003) Highly efficient production and characterization of T-DNA plants for rice (Oryza sativa) functional genomics. TAG Theor Appl Genet 106 (8):1396-1408. doi:10.1007/s00122-002-1184-x

Schlub RL, Smith LJ, Datnoff LE, Pernezny K (2009) An overview of target spot of tomato caused by Corynespora cassiicola. Acta Hortic 808:25-28 
Schoch CL, Crous PW, Groenewald JZ, Boehm EWA, Burgess TI, de Gruyter J, de Hoog GS, Dixon LJ, Grube M, Gueidan C, Harada Y, Hatakeyama S, Hirayama K, Hosoya T, Huhndorf SM, Hyde KD, Jones EBG, Kohlmeyer J, Kruys Å, Li YM, Lücking R, Lumbsch HT, Marvanová L, Mbatchou JS, McVay AH, Miller AN, Mugambi GK, Muggia L, Nelsen MP, Nelson P, Owensby CA, Phillips AJL, Phongpaichit S, Pointing SB, Pujade-Renaud V, Raja HA, Rivas Plata E, Robbertse B, Ruibal C, Sakayaroj J, Sano T, Selbmann L, Shearer CA, Shirouzu T, Slippers B, Suetrong S, Tanaka K, Volkmann-Kohlmeyer B, Wingfield MJ, Wood AR, Woudenberg JHC, Yonezawa H, Zhang Y, Spatafora JW (2009) A class-wide phylogenetic assessment of Dothideomycetes. Stud Mycol 64:1-15 Shamsul KAS, Shamsuri MH (1996) Current status of Corynespora leaf fall in Malaysia. In: Proceeding of the workshop on Corynespora Leaf Fall disease. Medan, Indonesia, pp 21-28

Sinulingga W, Suwarto, Soepena H (1996) Current status of Corynespora leaf fall on Hevea rubber in Indonesia. In: Proceeding of the workshop on Corynespora Leaf Fall Disease. Medan, Indonesia, pp 7-11
Suryanarayanan TS, Murali TS, Venkatesan G (2002) Occurrence and distribution of fungal endophytes in tropical forests across a rainfall gradient. Can J Bot 80:818-826

Suryanarayanan T, Murali T, Thirunavukkarasu N, Govinda Rajulu M, Venkatesan G, Sukumar R (2011) Endophytic fungal communities in woody perennials of three tropical forest types of the Western Ghats, southern India. Biodivers Conserv 20(5):913928. doi:10.1007/s10531-011-0004-5

Tamura K, Dudley J, Nei M, Kumar S (2007) MEGA4: Molecular Evolutionary Genetics Analysis (MEGA) software version 4.0. Mol Biol Evol 24:1596-1599

Wahounou PJ, Tran Van Canh C, Keli JZ, Eschbach JM (1996) Development of Corynespora cassiicola and Colletotrichum gloesporioides leaf fall diseases in rubber plantation in Africa. In: Proceeding of the workshop on Corynespora Leaf Fall disease. Medan, Indonesia, pp 99-106

White T, Bruns T, Lee S, Taylor J (1990) Amplification and direct sequencing of fungal ribosomal RNA genes for phylogenetics. Academic, San Diego 